\title{
Køn, public service motivation og adfærd
}

Køn kan have betydning for offentlig serviceproduktion, fordi kvinders motivation er anderledes end mænds. Den relevante litteratur (om public service motivation) har imidlertid ikke beskæftiget sig systematisk med, hvad der teoretisk kan forklare effekten af personlige karakteristika, og de eksisterende studier er også plaget af manglende kontrol for forskellige jobfunktioner. Denne artikel undersøger derfor dels køns generelle betydning for typen af public service motivation for 1.243 danske lønmodtagere fordelt på 15 forskellige jobfunktioner og dels køns direkte og indirekte påvirkning af adfærden på et helt specifikt område. Dette område er fysioterapi til almindelige og vederlagsfrie sygesikringspatienter, og testen af de teoretiske forventninger kombinerer registerdata og spørgeskemadata. Vi finder, at køn har den forventede betydning for public service motivation, men der er stadig en direkte effekt af køn (og alder) på fysioterapeuternes adfærd. Artiklen bidrager dermed til vores viden om, hvordan køn påvirker såvel motivation som adfærd.

\section{Indledning}

Eksisterende analyser af adfærden hos offentlige serviceproducenter har i stort omfang overset de ansattes personlige karakteristika (Nielsen og Salomonsen, 2010). Køn og alder inddrages godt nok ofte som kontrolvariable, men effekterne teoretiseres sjældent, og vi ved derfor ikke ret meget om mekanismerne bag disse forholds betydning for adfærden. Denne artikel fokuserer på betydningen af køn, men effekten af alder undersøges og diskuteres også. Ambitionen er derfor at undersøge, om forholdet mellem køn og forvaltning er væsentligt i den forstand, at køn påvirker medarbejdernes indsats systematisk.

Køn er specielt interessant, fordi nyere forskning tyder på, at kvinder gennemsnitligt er mere empatiske end mænd. Neurologiske eksperimenter viser således en kønsforskel på mænd og kvinders hjernemæssige reaktioner på andre menneskers smerte (Yang et al., 2009: 181), hvilket svarer godt til de psykologiske forskningsresultater (Baron-Cohen, 2003; 2007), der viser, at kvinder i gennemsnit er bedre til at relatere sig til følelsesmæssige tilstande hos andre.

Spørgsmålet er, hvilken betydning kønsforskellen i empati kan tænkes at have for motivation og adfærd i forhold til leveringen af offentlige ydelser. Vi 
argumenterer for, at forskellen i empati gør køn relevant for ansattes public service motivation (PSM), dvs. deres orientering imod at levere service til mennesker med det formål at gøre godt for andre og for samfundet. Denne type motivation kan findes i både den offentlige og den private sektor og skal ikke forveksles med "public sector motivation" (som kan forstås som motiverne til at arbejde i den offentlige sektor jf. Perry og Hondeghem, 2008: 3). Inden for PSM-litteraturen er dimensionen "compassion" specielt relevant. Denne dimension handler om at være motiveret til at bidrage samfundsmæssigt ud fra ønsket om at beskytte og hjælpe (svage) samfundsmæssige grupper (Perry \& Wise, 1990; Perry, 1996). Vores argument er, at den kønsbetingede forskel i evnen til empati gør, at kvinder i gennemsnit er lidt bedre i stand til at leve sig ind $i$ andres situation, og at dette gør, at flere af dem i høj grad bliver motiveret af at hjælpe og beskytte dem, der har det svært. De øvrige PSM-dimensioner er "commitment to the public interest" og "attraction to public policy making", og disse inddrages primært for at sikre, om det faktisk er via compassion-dimensionen, at køn har betydning for adfærden.

Når det er interessant, om køn påvirker de forskellige PSM-dimensioner, skyldes det, at PSM har betydning for adfærd og performance i offentlig serviceproduktion (Alonso \& Lewis, 2001; Vandenabeele, 2009 og Leisink \& Steijn, 2009). PSM er dermed en mulig mekanisme, hvorigennem køn kan påvirke adfærden. Denne artikel undersøger, hvordan køn påvirker ansattes grad af PSM, og hvordan køn (direkte og via PSM) påvirker adfærden.

Datagrundlaget er todelt. Vi undersøger sammenhængen mellem køn og PSM i en survey-undersøgelse af 1.243 danske lønmodtagere, hvor PSM måles ved et sæt af velafprøvede spørgsmål. Lønmodtagernes adfærd kan naturligvis ikke måles direkte i en survey. Undersøgelsen af køns effekt på adfærd sker derfor blandt fysioterapeuter med individuel fysioterapipraksis, hvor det er muligt at identificere objektive adfærdsmål. For at få information om tilstrækkeligt mange fysioterapeuters køn, motivation og adfærd har vi lavet en separat spørgeskema- og registerundersøgelse af denne gruppe. Dette skæve design gør det muligt at gå i dybden med fysioterapeuterne (hvor vi har objektive adfærdsmål) samtidig med, at relationen mellem køn og motivation undersøges for et bredt udsnit af danske lønmodtagere. Ved dels at undersøge de generelle kønsforskelle i motivation og dels at fokusere snævert på (motivations- og) adfærdsforskelle for en enkelt faggruppe opnår vi generaliserbar viden om køn og motivation kombineret med specifik viden om, hvordan motivation og køn påvirker konkret adfærd. Artiklen begynder med en diskussion af de teoretiske forventninger efterfulgt af en redegørelse for data og metoder. Derefter følger resultaterne, hvor vi først analyserer køns betydning for PSM og derefter kigger 
på betydningen af såvel PSM som køn for individuel adfærd. Endelig diskuterer konklusionen artiklens bidrag til vores forståelse af relationerne mellem køn, motivation og adfærd.

\section{Teoretiske forventninger:}

\section{Køn, public service motivation og adfærd}

Det første relevante spørgsmål er, hvorfor man overhovedet kan forvente en kønseffekt på motivation og adfærd. Det kan man, fordi psykologisk forskning (Baron-Cohen, 2003; Connellan et al., 2000; Baron-Cohen, 2007; Eisenberg et al., 1991; Feingold, 1994) og hjerneforskning (Han et al., 2008; Yang et al., 2009) har vist, at kvinder som udgangspunkt gennemsnitligt har større empatiske evner end mænd. Eksempelvis reagerer kvinders hjerner kraftigere på billeder af legemsdele (hænder og fødder) i smertefulde situationer (Han et al., 2008: 90). Eftersom empati handler om spontant at kunne sætte sig ind i andres tanker og følelser samt intuitivt at kunne indstille sig herpå, kan denne forskel have betydning for, hvordan man handler i sin rolle som producent af offentlig service (Nielsen og Salomonsen, 2010). Hvis man er god til at sætte sig ind $\mathrm{i}$ andres tanker og følelser (herunder deres smerte), prioriterer man måske anderledes mellem forskellige typer brugere, og man udfører måske selve serviceproduktionen anderledes. Det er vigtigt at understrege, at det udelukkende handler om gennemsnitsforskelle, og vi kan heller ikke være sikre på, at de initiale forskelle har betydning, når mænd og kvinder producerer offentlig service.

Den kønsbetingede forskel i empati kan blandt andet tænkes at påvirke adfærden gennem de ansattes motivation. Motivation kan forstås som drivkraften bag målrettede handlinger (Beck Jørgensen \& Andersen, 2010: 35), og i denne sammenhæng ses motivation som den energi, en ansat er villig til at lægge bag opnåelsen af en målsætning i forbindelse med sit job. Især graden af public service motivation kan tænkes at have betydning, fordi denne motivationsform jf. James Perry og Annie Hondeghem (2009: 6) handler om individets orientering imod at levere service til mennesker med det formål at gøre godt for andre og for samfundet.

Public service motivation består af flere dimensioner. Den vigtigste dimension i denne sammenhæng kaldes "compassion". Den handler om at bidrage samfundsmæssigt ud fra ønsket om at beskytte og hjælpe (svage) samfundsmæssige grupper (Perry og Wise, 1990). Motivationen til at gøre det godt for hele samfundet kaldes derimod for "commitment to the public interest". Det handler om at leve op til en samfundsmæssig forpligtelse, og dimensionen er i litteraturen (Perry og Wise, 1990) især knyttet til at følge normer for, hvordan 
man udfører sit arbejde. Dimensionen "attraction to public policy making" er knyttet til at påvirke den førte politik, og dele af litteraturen medtager også dimensionen "self-sacrifice". Sidstnævnte kan forstås som individets vilje til at tilsidesætte egne behov til fordel for at hjælpe andre og/eller samfundet via levering af offentlige ydelser. Coursey og Pandey (2007) dokumenterer imidlertid, at "self-sacrifice" med fordel kan udelades pga. en høj korrelation med "commitment to the public interest"-dimensionen. I artiklen her følger vi deres anbefaling og arbejder med dimensionerne vist i figur 1 .

Figur 1. Dimensionerne i public service motivation

Public service motivation

Commitment to the public interest (normbaseret, samfundsmæssig

Compassion (betænksomhed og

forpligtelse) beskyttelse af (svage) samf. grupper)

Attraction to public policy making

(instrumentel samf. andring)

Der er uenighed i litteraturen om, hvorvidt kvinder eller mænd har højest grad af PSM. Perry (1997: 190) viser, at mænd scorer højere på "commitment to the public interest"- og "self-sacrifice"-dimensionerne. DeHart-Davis et al. (2006) finder derimod, at kvinder har højere grad af PSM end mænd (DeHart-Davis et al., 2006). Det mest sikre resultat vedrørende køn og PSM er dog, at kvinder har højere grad af compassion end mænd (Camilleri, 2007). Det giver god teoretisk mening pga. de nævnte initialforskelle i empati; hvis kvinder i højere grad spontant sætter sig ind i andres tanker og følelser, er det nærliggende at forvente, at denne højere grad af empati øger deres motivation til at beskytte og hjælpe grupper, der opfattes som svagere eller mere værdigt trængende, hvilket igen kan have betydning for deres adfærd. Teoretisk forventer vi med andre ord en positiv effekt af empati på graden af compassion. En anden grund til at forvente, at kvinder har højere grad af compassion, er, at denne type motivation kulturelt er konstrueret som noget feminint (Stivers, 2002: 58). De biologiske og kulturelle forklaringer udelukker ikke hinanden. Eftersom begge forklaringer leder til den samme forventning i denne sammenhæng, nemlig at der findes en kobling mellem køn og compassion, er forholdet mellem de to typer af forklaringer, altså om sammenhængen skyldes "nature, nurture, or a combination of both" (DeHart-Davis, Marlowe \& Pandey, 2006: 876), mindre vigtig for denne artikels problemstilling. Vi vil først og fremmest undersøge, om køn faktisk har en betydning for $p u b$ lic service motivation og derigennem for adfærd for producenter af offentlige ydelser. Specifikt forventer vi, at kvinder har højere grad af compassion end 
mænd. Køn kan samtidig sagtens tænkes at have betydning for de andre PSM-dimensioner. Perry (1997) har som nævnt vist, at mænd scorer højere på "commitment to the public interest"-dimensionen (og på den tæt forbundne "self-sacrifice"-dimension). Det er også veldokumenteret (Welch, 1977; Jennings, 1983; Siim, 1999), at køn hænger statistisk sammen med politisk interesse, således at kvinder i gennemsnit er mindre politisk interesserede end mænd. Det er nærliggende at forvente, at det fører til en forskel i "attraction to public policy making". Argumenterne for at forvente kønsforskelle for disse to PSM-dimensioner er imidlertid ret svage, fordi litteraturen ikke fremfører teoretiske begrundelser for forskellene, ligesom forskellene heller ikke er empirisk konsistente (DeHart-Davis et al., 2006). Derfor inddrages dimensionerne alene i analyserne som kontrolvariable. Formålet er at se, om $k ø n$ virker gennem andre motivationsdimensioner end compassion. For at undersøge, om eventuelle kønsforskelle kunne være et resultat af forskelle mellem kvinde- og mandsdominerede jobfunktioner, kontrollerer vi desuden for lønmodtagernes jobfunktion og sektortilknytning.

Kønsbetingede motivationsforskelle er især relevante, hvis de påvirker de offentlige ydelser. Spørgsmålet er derfor, om der kan spores en effekt på adfærden hos producenterne af disse offentlige ydelser. Om en sådan effekt findes, og hvordan den må forventes at se ud, afhænger af, hvilken adfærd der er tale om. Jo mere adfærd relaterer sig til at hjælpe andre og samfundet, desto mere nærliggende er det, at PSM påvirker de ansattes indsats. Virkningen varierer formodentlig også for de tre PSM-dimensioner. Især hvis det handler om adfærd, som de ansatte opfatter som rettet mod at hjælpe eller beskytte udsatte grupper, kan compassion tænkes at spille en rolle. "Attraction to public policy making" vil især være relevant, når adfærden relaterer sig til det politiske systems beslutninger og prioriteringer, mens "commitment to the public interest"-dimensionen især kan tænkes at have betydning, hvis adfærdens mål handler om at gøre det godt samfundsmæssigt.

Den centrale udfordring i undersøgelsen af adfærd er at identificere et målbart og sammenligneligt adfærdsmål. Det er svært at forestille sig adfærdsmål, der tillader sammenligninger på tværs af forskellige erhverv. Vi går derfor i dybden med en enkelt faggruppe, når vi undersøger adfærdsdelen af problemstillingen. Vi har af flere grunde valgt at undersøge fysioterapeuter. For det første er der både kvindelige og mandlige fysioterapeuter, og især blandt de praktiserende fysioterapeuter er kønsfordelingen ikke helt skæv. For det andet er deres adfærd relateret til dels at gavne svage enkeltpatienter og dels at gøre en samfundsmæssig forskel (fx i form af forebyggelse). For det tredje har praktiserende fysioterapeuter to patientgrupper, som giver mulighed for at konstruere 
et adfærdsmål. De såkaldt vederlagsfri patienter har et kronisk handicap og modtager fysioterapi uden brugerbetaling efter henvisning fra en praktiserende læge. De resterende patienter betaler selv en del af regningen, men der kræves stadig henvisning. Fysioterapeuten modtager den samme betaling for behandlingen af de to typer af patienter (efter at data blev indsamlet sågar mindre for de vederlagsfrie patienter). De vederlagsfri patienter er i almindelighed mere tidskrævende, samtidig med at gruppen opfattes som mere "trængende" end de øvrige patienter. Formanden for Danske Fysioterapeuter, Johnny Kuhr, udtrykker det således: ${ }^{1}$

Det er et stort plus, at der er kommet en ordning omkring vederlagsfri fysioterapi, så borgere med et handicap kan få en løbende behandling, der kan (...) give dem noget livskvalitet. (...) De kræver mere - mandskab, flere ressourcer og mere tid typisk - end den fuldstændigt selvhjulpne patient, der er hurtigt ud og ind ad døren og klarer sig selv med påklædning og afklædning og så videre. Så det er en helt anden opgave, men det er gynger og karruseller (interview med Johnny Kuhr)

Prioriteringen af de vederlagsfri patienter er derfor omkostningsfuld for fysioterapeuten i den forstand, at det er lidt mere tidskrævende at levere ydelserne, samtidig med at honoraret ikke er højere, end hvad der gives for tilsvarende ydelser til andre patienter. Forudsætningen for, at køn og motivation kan have betydning for adfærdsvariablen, er, at fysioterapeuterne har en vis indflydelse på deres patientsammensætning. Det kan de have gennem flere mekanismer. Enhederne i analysen er fysioterapeuter med individuelle ydernumre, som godt kan have lokale- og receptionsfællesskab med andre fysioterapeuter. Hvis de selv ejer lokaler, hvor andre fysioterapeuter lejer sig ind, kan de vælge at få bestemte typer patienter, når disse henvender sig til den fælles reception. Som lokalelejere har de nok ikke helt samme valgmulighed, hvilket vi som diskuteret senere kontrollerer statistisk for. Hvis en fysioterapeut ikke deler reception med andre, kan vedkommende bruge ventetiden for forskellige patientgrupper til at regulere patientsammensætningen, og de har også mulighed for at specialisere sig i bestemte typer patienter og signalere dette til patienter og henvisende læger. Endelig kan de afslutte eller videresende "uønskede" patienter. Det er ikke muligt alene på baggrund af data om sammensætningen af ydelserne at skelne mellem disse mekanismer, men de ret store variationer $\mathrm{i}$ patientsammensætning mellem forskellige fysioterapeuter med klinik i samme geografiske område tyder på, at fysioterapeuterne i et vist omfang kan påvirke patientsammensætningen. 
Såvel graden af "commitment to the public interest"-motivation som graden af compassion hos de enkelte fysioterapeuter forventes at have en effekt på deres prioritering af vederlagsfrie patienter, fordi fysioterapeuterne selv opfatter deres arbejde med disse patienter både som et samfundsbidrag og som en hjælp til den specifikke patientgruppe. "Attraction to public policy making" forventes derimod ikke at have betydning for denne type adfærd. Det udelukker naturligvis ikke, at denne PSM-dimension kan have betydning for forhold som rådgivning af politikere og implementering af politiske beslutninger (se Hansens artikel i dette temanummer).

Figur 2 viser den teoretiske model. Vi forventer som nævnt, at køn har betydning for en underdimension af PSM, nemlig compassion. Hvis compassion som forventet samtidig har en effekt på adfærden i fysioterapeuternes prioritering af vederlagsfrie patienter, vil køn have en indirekte effekt på adfærden. Vi undersøger samtidig, om køn har en direkte adfærdseffekt, og om forventningen om en effekt af "commitment to the public interest"-dimensionen holder stik. Figuren indikerer også, at der skal kontrolleres for en række variable. Det gælder særligt alder. Litteraturen forventer, at individers grad af PSM vokser med alderen (Pandey \& Stazyk, 2008: 102). Derfor indgår alder som en kontrolvariabel i alle vores analyser. Litteraturen har også fundet, at ansættelsessektor har betydning for PSM, særligt for "commitment to the public interest"dimensionen (Andersen et al., 2009), selvom man er gået væk fra Perry og Wises (1990) oprindelige opfattelse af begrebet som alene funderet i den offentlige sektor (Steen, 2008). Derfor indgår både offentligt og privat ansatte i analyserne. Endelig finder Steinhaus og Perry (1996), at branche forklarer endnu mere variation i PSM end tilknytning til den offentlige sektor, og vi kontrollerer derfor både for jobfunktion og ansættelsessektor i analyserne af køn og PSM. Kontrollen for jobfunktion betyder også samtidig en kontrol for uddannelse, da individerne inden for de 15 undersøgte funktioner har stort set samme uddannelse. I adfærdsanalyserne holdes sektor, uddannelse og jobfunktion konstant (eftersom kun fysioterapeuter i den private sektor undersøges), mens der kontrolleres for typen af klinik. Mest relevant er det, om klinikken er fysisk beliggende i bestemte lokaler, eller om fysioterapeuten kører rundt til forskellige patienter. Sidstnævnte har nemlig typisk flere vederlagsfrie patienter. Det er også relevant at se på, om ydernummeret er et deltidsydernummer (fordi kvinder oftere er på deltid, og deltid kan give en lidt anden prioritering mellem patienttyperne). Vi inddrager også, om personen lejer sig ind i lokaler, der tilhører en anden fysioterapeut, eller selv ejer sin klinik (fordi en lejer ved delt reception kan være nødt til at tage flere vederlagsfrie patienter pga. pres fra ejeren af lokalerne). 
Figur 2. Illustration af teoretisk model

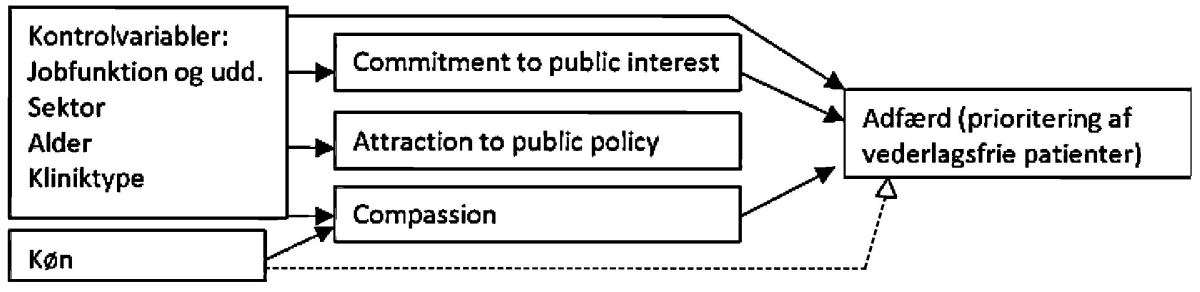

\section{Data og metoder}

Undersøgelsen består som nævnt af en spørgeskemaundersøgelse til danske lønmodtagere og af en undersøgelse af praktiserende fysioterapeuter. Sidstnævnte består af registerdata kombineret med en spørgeskemaundersøgelse af alle danske fysioterapeuter. Datakilderne vil kort blive beskrevet nedenfor. Registerdata kommer fra sygesikringsregistret (ydelsesantallet) og yderregisteret (oplysninger om de individuelle fysioterapeuter). Disse data er leveret af Sundhedsstyrelsen. Der anvendes i denne undersøgelse kun ydernumre, der entydigt kan knyttes til enkeltpersoner i spørgeskemaundersøgelsen. Vores registerdata er fra perioden januar til juni 2008.

Spørgeskemaundersøgelsen blandt almindelige danske lønmodtagere blev gennemført i juni 2009 af analysefirmaet Zapera. Det skete i lighed med fysioterapiundersøgelsen med et webbaseret spørgeskema. Respondenterne var $\mathrm{Za}$ peras webpanel, som består af tilnærmelsesvist repræsentative 25-64-årige danskere. Kun lønmodtagere var del af målgruppen. Givet at det er et webpanel, kan man ikke tale om en egentlig svarprocent; skemaet blev udsendt til 15.000 personer, og det blev lukket, da der var indkommet 3.333 gyldige svar. Pga. vigtigheden af kontrol for jobfunktioner indeholder analyserne kun de respondenter, hvor der i stikprøven var flere end 25 personer med samme jobfunktion (for at sikre, at vi kunne inddrage dummyvariable for disse). De analyserede jobfunktioner er gengivet i tabel 1 .

Spørgeskemaundersøgelsen til fysioterapeuterne fandt sted i februar og marts 2009. Der blev udsendt en pilotundersøgelse til 100 fysioterapeuter, mens hovedundersøgelsen blev udsendt til de resterende 7.777 fysioterapeuter og fysioterapeutstuderende, som vi havde gyldige e-mail-adresser for. Idet vi havde e-mails for 75 procent af af samtlige fysioterapeuter i landet, var det tilnærmelsesvist en populationsundersøgelse. 4.985 besvarede skemaet, hvilket giver en svarprocent på 64 . Ud af de 4.985 anvendte vi 3.826 til analysen af køn og motivation, fordi vi kun ønsker at se på fysioterapeuter, som i enten 
Tabel 1. Oversigt over undersøgte jobfunktioner

\begin{tabular}{lc}
\hline Betegnelse & Antal \\
\hline Administrationsarbejde & 139 \\
Arkitekt-, ingeniør- og designarbejde & 64 \\
Assistentarbejde inden for sundhed & 27 \\
EDB-arbejde & 180 \\
Jurist- og advokatarbejde & 26 \\
Kontorarbejde & 131 \\
Naturvidenskabelig tekniker & 74 \\
Omsorgsarbejde & 147 \\
Overvågnings- og vagtarbejde & 29 \\
Personalearbejde/-ledelse & 40 \\
Registreringsarbejde & 45 \\
Skolelærer & 189 \\
Specialfunktioner vedrørende organisation & 74 \\
Sygeplejerske & 78 \\
\hline I alt & 1.243 \\
\hline
\end{tabular}

Note: DISCO 88-klassifikationen kan ses på http://www.dst.dk/Vejviser/Portal/loen/DISCO/DISCO-88.aspx

den offentlige eller den private sektor producerer offentlige ydelser. Analysen af adfærd bygger på de 562 individuelt praktiserende fysioterapeuter, hvor vi har oplysninger om såvel individuel adfærd som alder, køn og PSM. I denne analyse indgår altså kun fysioterapeuter, der har deres egne patienter og individuelt afregner med regioner og kommuner. De kan imidlertid godt være en del af et klinikfællesskab i den forstand, at de deler lokaler med andre eller lejer lokaler hos en anden fysioterapeut, men det essentielle er, at vi kan undersøge deres individuelle adfærd, fordi registreringen af ydelser kun vedrører en fysioterapeut.

I begge spørgeskemaundersøgelser blev PSM-dimensionerne målt med tre batterier af spørgeskemaudsagn, som respondenterne erklærede sig enig eller uenig i (svarkategorierne er helt enig, delvist enig, hverken eller, delvist uenig og helt uenig). I målingen af public service motivation har vi forsøgt at lægge os så tæt som muligt på den internationale litteratur (jf. Perry, 1996 og Coursey \& Pandey, 2007). Tabel 2 gengiver spørgsmålsformuleringerne. Faktor- og reliabilitetsanalyser viser, at der kan konstrueres refleksive indeks for de tre dimensioner (se Andersen, Pallesen og Pedersen, 2009), og disse er omskaleret, så de alle går fra 0 til 100 (hvor 100 er maksimalt niveau af den specifikke type af PSM). 
Tabel 2. Målingen af de tre PSM-dimensioner

Attraction to public policy making

Jeg forbinder generelt politik med noget positivt

Jeg bryder mig ikke om politiske studehandler

Jeg har ikke særligt høje tanker om politikere

Commitment to the public interest

Jeg føler, at jeg bidrager til samfundet

Det er meget vigtigt for mig, at de offentlige ydelser er i orden

Jeg så helst, at offentligt ansatte gjorde det, der er bedst for hele samfundet, selvom det skulle gå ud over mine egne interesser

Det er min borgerpligt at gøre noget, der tjener samfundets bedste

Compassion

For mig er hensyntagen til andres velfærd en af de vigtigste værdier

Jeg bliver følelsesmæssigt berørt, når jeg ser mennesker i nød

Daglige begivenheder minder mig ofte om, hvor afhængige vi er af hinanden

\section{Køn, public service motivation og adfærd}

I dette afsnit præsenteres analysens resultater ved først at se på, hvordan køn påvirker PSM-dimensionerne (kontrolleret for alder, sektor og jobfunktion), efterfulgt af en analyse af betydningen af køn og PSM for individuel adfærd.

I forhold til "commitment to the public interest"-dimensionen af PSM er der ikke samme teoretiske grunde til at forvente betydelige kønsforskelle. Analyserne i tabel 4 viser, at der er en positiv effekt (kvinder har mere "commitment to the public interest" end mænd), men at sektor medierer denne sammenhæng (når man inddrager kontrol for ansættelsessektor, forsvinder den direkte sammenhæng mellem køn og "commitment to the public interest"). At være ansat i den offentlige sektor er således forbundet med at have højere "commitment to the public interest" (og flere kvinder end mænd er offentligt ansatte). I lighed med, hvad vi så for compassion, har alder en positiv effekt for "commitment to the public interest"-dimensionen. Vigtigst for den aktuelle problemstilling er dog, at køn ikke har nogen direkte betydning for "commitment to the public interest"-motivation kontrolleret for sektortilhørsforhold.

Forventningen fra litteraturen er som nævnt, at kvinders niveau af compassion-dimensionen af PMS er højere end mænds. Tabel 3 viser en række OLSregressioner, der klart bekræfter denne forventning. Model 3.1 viser, at køn og alder har en positiv effekt på denne dimension. I model 3.2 kontrolleres der 
Tabel 3. Køns betydning for compassion-motivation. Ansatte i 15 forskellige jobfunktioner (model 3.1-3.3) og fysioterapeuter (model 3.4). OLS-regressioner. 2009

\begin{tabular}{lcccc}
\hline & Model 3.1 & Model 3.2 & Model 3.3 & Model 3.4 \\
\hline (Konstant) & $52,580^{* * *}$ & $52,224^{* * *}$ & $59,513^{* * *}$ & $74,501^{* * *}$ \\
& $(0,000)$ & $(0,000)$ & $(0,000)$ & $(0,000)$ \\
Alder & $0,246^{* * *}$ & $0,224^{* * *}$ & $0,214^{* * *}$ & 0,048 \\
& $(0,000)$ & $(0,000)$ & $(0,000)$ & $(0,063)$ \\
Køn (1=kvinde) & $7,568^{* * *}$ & $6,598^{* * *}$ & $5,591^{* * *}$ & $4,466^{* * *}$ \\
& $(0,000)$ & $(0,000)$ & $(0,000)$ & $(0,000)$ \\
Sektor (1=offentlig) & & $3,503^{* * *}$ & 0,775 & $1,460^{*}$ \\
& & $(0,000)$ & $(0,517)$ & $(0,018)$ \\
Jobfunktion & & & 14 jobdummi- & Kun fysiote- \\
& & & er inkluderet & rapeuter \\
\hline $\mathrm{N}$ & 1230 & 1230 & 1230 & 3463 \\
$\mathrm{R}^{2}$ & 0,08 & 0,09 & 0,12 & 0,02 \\
\hline
\end{tabular}

Note: I tabel 1 er en liste over jobfunktionerne. ${ }^{*}: 0,05 \geq p>0,01 .^{* *}: 0,01 \geq p>0,001$.

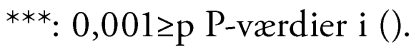

Tabel 4. Køns betydning for "commitment to the public interest"-motivation. Ansatte i 15 forskellige jobfunktioner (model 4.1-4.3) og fysioterapeuter (model 4.4). OLS-regressioner. 2009

\begin{tabular}{lcccc}
\hline & Model 4.1 & Model 4.2 & Model 4.3 & Model 4.4 \\
\hline Konstant $)$ & $69,804^{* * *}$ & $69,393^{* * *}$ & $75,181^{* * *}$ & $72,954^{* * *}$ \\
& $(0,000)$ & $(0,000)$ & $(0,000)$ & $(0,000)$ \\
Alder & $0,161^{* * *}$ & $0,136^{* * *}$ & $0,121^{* *}$ & $0,129^{* * *}$ \\
& $(0,000)$ & $(0,001)$ & $(0,004)$ & $(0,000)$ \\
Køn (1=kvinde) & $2,571^{* *}$ & 1,498 & 1,256 & $-0,554$ \\
& $(0,003)$ & $(0,095)$ & $(0,213)$ & $(0,411)$ \\
Sektor $(1=$ offentlig) & & $3,982^{* * *}$ & $2,315^{*}$ & $1,627^{* *}$ \\
& & 0,000 & $(0,024)$ & $(0,007)$ \\
Jobfunktion & & & 14 jobdummi- & Kun fysiote- \\
& & & er inkluderet & rapeuter \\
\hline $\mathrm{N}$ & 1224 & 1224 & 1224 & 3182 \\
$\mathrm{R}^{2}$ & 0,02 & 0,04 & 0,05 & 0,01 \\
\hline $\mathrm{Note}$ & & & & \\
\hline
\end{tabular}

Note: I tabel 1 er en liste over jobfunktionerne. ${ }^{*}: 0,05 \geq p>0,01 .{ }^{* *}: 0,01 \geq p>0,001$.

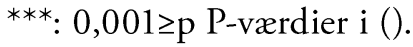


for, om der er tale om offentligt eller privat ansatte, og i model 3.3 for, hvilken jobfunktion der er tale om. Effekten af køn er i alle modeller klart signifikant, og kvinder har i alle modeller markant højere grad af compassion end mænd. Alder viser sig generelt (som forventet i litteraturen) at have en positiv effekt på compassion, hvorimod model 3.3 viser, at offfentlig ansættelse kun har en meget begrænset (eller slet ingen) effekt, når der kontrolleres for jobfunktion. Af hensyn til sammenligneligheden med de senere analyser af køns indvirkning på adfærd viser vi i model 3.4 resultaterne af en tilsvarende analyse blot for gruppen fysioterapeuter.

Tabel 5. Køns betydning for "attraction to public policy making"-motivation. Ansatte i 15 forskellige jobfunktioner (model 5.1-5.3) og fysioterapeuter (model 5.4). OLS-regressioner. 2009

\begin{tabular}{lcccc}
\hline & Model 5.1 & Model 5.2 & Model 5.3 & Model 5.4 \\
\hline (Konstant) & $49,406^{* * *}$ & $49,433^{* * *}$ & $50,288^{* * *}$ & $45,976^{* * *}$ \\
& $(0,000)$ & $(0,000)$ & $(0,000)$ & $(0,000)$ \\
Alder & $-0,147^{* *}$ & $-0,145^{* *}$ & $-0,154^{* *}$ & $-0,093^{* *}$ \\
& $(0,007)$ & $(0,009)$ & $(0,006)$ & $(0,002)$ \\
Køn (1=kvinde) & $-2,531^{*}$ & $-2,454^{*}$ & $-1,879$ & $-1,682^{*}$ \\
& $(0,026)$ & $(0,037)$ & $(0,154)$ & $(0,035)$ \\
Sektor (1=offentlig) & & $-0,296$ & $-0,374$ & $-1,059$ \\
& & $(0,801)$ & $(0,782)$ & $(0,131)$ \\
Jobfunktion & & & 14 jobdummi- & Kun fysiote- \\
& & & er inkluderet & (ikke vist) \\
\hline $\mathrm{N}$ & 1202 & 1202 & 1202 & 3446 \\
$\mathrm{R}^{2}$ & 0,01 & 0,01 & 0,03 & 0,01 \\
\hline
\end{tabular}

Note: I tabel 1 er en liste over jobfunktionerne. ${ }^{*}: 0,05 \geq p>0,01 .^{* *}: 0,01 \geq p>0,001$. ***: 0,001 pp P-værdier i ().

Det fremgår af tabel 5, at køn har en vis betydning for graden af "attraction to public policy making". Mænd er således mere tiltrukket af politik end kvinder. Det skal dog bemærkes, at sammenhængen er ret svag; i model 5.3 endda insignifikant. Kønsforskellen er endnu mindre i model 5.4, men det store antal respondenter $g ø r$, at den alligevel er signifikant. Vores fortolkning af denne sammenhæng er, at den er et udtryk for kønsforskelle i politisk interesse. Baggrunden for denne fortolkning er, at andre dele af statskundskaben har dokumenteret en kønsforskel i politisk deltagelse (Welch, 1977; Jennings, 1983), 
men om denne fortolkning er rigtig, må mere detaljerede studier afgøre. De modsatrettede kønseffekter for de forskellige dimensioner af PSM er en mulig forklaring på de modstridende empiriske resultater i de eksisterende undersøgelser af sammenhængen mellem køn og PSM. Alder har en negativ effekt på graden af "attraction to public policy making", hvorimod ansættelse i den offentlige sektor ikke betyder noget.

Resultaterne for fysioterapeuterne (model 3.4, 4.4 og 5.4) svarer i meget høj grad til den bredere undersøgelse af forskellige lønmodtagere, og hvis man yderligere indsnævrer analysen af køn og motivation til fysioterapeuter med

Tabel 6. OLS-regressioner af individuel adfærd hos praktiserende fysioterapeuter (andel vederlagsfrie patienter). Ustandardiserede koefficienter

\begin{tabular}{|c|c|c|c|}
\hline & Model 6.1 & Model 6.2 & Model 6.3 \\
\hline \multirow[t]{2}{*}{ Konstant } & $0,098^{* * *}$ & 0,046 & $0,077^{*}$ \\
\hline & $(0,000)$ & $(0,142)$ & $(0,027)$ \\
\hline \multirow[t]{2}{*}{ Køn (kvinde=1) } & $0,037^{* *}$ & & $0,027^{* *}$ \\
\hline & $(0,012)$ & & $(0,005)$ \\
\hline \multirow[t]{2}{*}{ Alder } & $0,002^{* * *}$ & & 0,000 \\
\hline & $(0,001)$ & & $(0,705)$ \\
\hline \multirow[t]{2}{*}{ Commitment to the public interest } & & $0,001^{* *}$ & $0,001^{* *}$ \\
\hline & & $(0,015)$ & $(0,003)$ \\
\hline \multirow[t]{2}{*}{ Attraction to public policy making } & & 0,000 & 0,000 \\
\hline & & $(0,154)$ & $(0,488)$ \\
\hline \multirow[t]{2}{*}{ Compassion } & & $0,001^{* *}$ & 0,000 \\
\hline & & $(0,020)$ & $(0,746)$ \\
\hline \multirow[t]{2}{*}{ Har været ansat i off. sektor } & & & $-0,005$ \\
\hline & & & $(0,649)$ \\
\hline \multirow[t]{2}{*}{ Ikke fysisk klinik (ref.: klinik) } & & & $0,543^{* * *}$ \\
\hline & & & $(0,000)$ \\
\hline \multirow[t]{2}{*}{ Deltidsydernummer } & & & 0,000 \\
\hline & & & $(0,975)$ \\
\hline \multirow[t]{2}{*}{ Lejer (reference: Ejer) } & & & $0,028^{* *}$ \\
\hline & & & $(0,009)$ \\
\hline $\mathrm{N}$ & 0,042 & 0,028 & 0,472 \\
\hline $\mathrm{R}^{2}$ & 562 & 542 & 521 \\
\hline
\end{tabular}

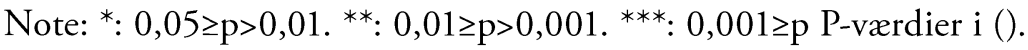


individuelt ydernummer (ikke vist her), får man stort set de samme resultater som for alle fysioterapeuter. I forhold til første del af problemstillingen kan vi således konkludere, at køn har en betydning for graden af PSM, men at det primært lader til at være i forhold til compassion-dimensionen. Spørgsmålet er så, om denne dimension (og køn i sig selv) har en betydning for adfærden.

Tabel 6 viser en række analyser af individuelt praktiserende fysioterapeuters prioritering af vederlagsfrie patienter. Som nævnt er dette adfærdsmål valgt, fordi 17 kvalitative interviews med fysioterapeuter viste, at høj prioritering af vederlagsfrie patienter anses for at være "godgørende" i forhold til en værdigt trængende gruppe, samtidig med at denne patienttype er lidt mere tidskrævende, uden at det reflekteredes i højere honorarer. På baggrund af disse karakteristika forventer vi, at fysioterapeuter med høj grad af compassion og høj grad af "commitment to the public interest"-motivation prioriterer vederlagsfrie patienter højere. Model 6.1 viser betydningen af de personlige karakteristika hos fysioterapeuterne (uden motivationsvariablene). Både det at være ældre og det at være kvinde medfører en højere prioritering af de vederlagsfrie fysioterapipatienter.

Hvis motivationsvariablene analyseres alene (model 6.2), ses det som forventet, at både compassion- og "commitment to the public interest"-motivation fører til højere prioritering af de vederlagsfrie patienter, mens "attraction to public policy making"-motivation ingen effekt har. I model 6.3 inddrages både personlige karakteristika og motivationsvariablene, og der kontrolleres for klinikvariablene. Det viser sig, at det blandt motivationsvariablene kun er "commitment to the public interest"-dimensionen, der har betydning. Det tyder således stærkt på, at køn er fælles årsag til både compassion og adfærd. Køn har således en direkte effekt på adfærden kontrolleret for de øvrige variable i model 6.3.

\section{Konklusion}

Formålet med artiklen var at undersøge, hvordan køn påvirker graden af public service motivation, og hvordan køn (direkte og via public service motivation) påvirker adfærden. Analyserne af både det brede udsnit af danske lønmodtagere og af gruppen af fysioterapeuterne viser, at køn især påvirker graden af compassion-dimensionen. Det svarer til litteraturens fund og forventninger. Resultaterne vedrørende de to andre dimensioner af PSM ("commitment to the public interest" og "attraction to public policy making") er mere usikre. Der er en bivariat relation mellem køn og "commitment to the public interest"motivation, men den forsvinder, hvis man ser på offentligt og privat ansatte hver for sig. Kvinder har altså højere "commitment to the public interest", men det hænger sammen med, at de i højere grad er ansat i den offentlige sektor. I 
forhold til "attraction to public policy making" lader der til at være en svag tendens til, at mænd er mere tiltrukket af politik end kvinder, og det kan skyldes kønsforskelle i mulighederne for politisk engagement. Det vigtigste fund vedr. problemstillingens første del er dog, at kvinder systematisk har et højere niveau af compassion-dimensionen af public service motivation.

Køn har imidlertid en klar effekt på medarbejdernes adfærd, som i denne artikel er målt som fysioterapeuternes prioritering af vederlagsfrie patienter. Kvinder prioriterer disse patienter højere. Fysioterapeuternes grad af compassion har ikke betydning for adfærden, når der kontrolleres for køn. Samtidig viser det sig, at køn har en direkte effekt på adfærden. Når adfærd måles som fysioterapeuters prioritering af forskellige patientgrupper, er konklusionen altså, at kønsforskellen ikke skyldes mænds og kvinders forskellige grad af compassion. Graden af "commitment to the public interest"-motivation viser sig at påvirke adfærden, men køn har ikke nogen betydning for "public interest"dimensionen, når vi tager højde for de ansattes sektortilknytning. Selvom vi således er kommet et stykke ad vejen i forhold til at forstå relationerne mellem køn, motivation og adfærd, tyder resultaterne på, at køns betydning for adfærd også går igennem andre mekanismer end public service motivation.

Køn har altså en klar effekt på både PSM-dimensionen compassion og på fysioterapeuters prioritering af patientkategorier, der kan opfattes som mere trængende. Disse to effekter har en ganske positiv klang. Det forekommer intuitivt at være godt, hvis en offentlig indsats præges af compassion og sikrer en prioritering af trængende grupper. Samtidig har begrebet empati vel også flere positive end negative konnotationer. Det er imidlertid ikke nødvendigvis et gode, at prioriteringer inden for offentlig serviceproduktion er præget af empati og/eller compassion. En indsats, der er motiveret af en høj grad af compassion, er ikke nødvendigvis mere nyttig end en indsats, der er motiveret af et ønske om for eksempel at gøre sit job ordentligt eller at opnå en forfremmelse. På samme måde er det ikke i alle situationer en fordel, at individuel motivation hos producenterne bestemmer prioriteringen mellem bestemte borgere eller opgaver. Sådanne prioriteringer kan sagtens tænkes at være i modstrid med legitime politiske beslutninger. I det konkrete tilfælde har opprioritering af vederlagsfri ydelser ikke været et politisk ønske, og for at undgå overskridelse af den økonomiske ramme for vederlagsfrie patienter blev taksterne for de vederlagsfrie ydelser nedsat i 2009 (KL, 2009).

Artiklen har sine begrænsninger, hvoraf den vigtigste er, at der er tale om et tværsnitsstudium, hvis formål er at undersøge kausalitet. Det er ret klart, at køn bliver bestemt før de andre variable, så der er ikke så meget tvivl om køns bruttoeffekt på motivation og køn. Om valget af jobfunktion og sektor bestem- 
mes før eller efter graden af PSM, er imidlertid et stort diskussionsemne i litteraturen (Lewis \& Frank, 2002; Bright, 2005; Vandenabeele, 2008). Det mest realistiske er nok, at påvirkningen går begge veje. Derfor kontrollerer vi for den socialisering, der sker efter, at man er kommet ind i en given sektor og en given jobfunktion. En begrænsning i forhold til den undersøgte adfærd er, at vi ikke belyser de mekanismer, fysioterapeuterne bruger til at påvirke deres patientsammensætning. Det er plausibelt, at denne også kan afhænge af patienterne og af klinikkens beliggenhed. Tilbage står, at de vederlagsfrie patienter havner hos kvinderne, og at der er systematisk samvariation mellem fysioterapeuternes individuelle motivation ("commitment to the public interest"-dimensionen) og deres patientsammensætning. Det er klart, at vi i denne artikel ikke giver noget endeligt svar på køns betydning for motivation og adfærd. Det kan meget vel tænkes, at køn og motivations specifikke påvirkning af adfærden afhænger af, hvilket adfærdsmål vi kigger på, som Nielsen også demonstrerer i dette temanummer. Nærværende analyse er ikke desto mindre et bidrag til debatten om, hvornår, hvordan og hvor meget køn påvirker produktionen af offentlige ydelser. Derudover demonstrerer artiklen, at alder også påvirker såvel motivation som adfærd. Det tyder på, at fremtidige studier af individuel adfærd med fordel kan tage personlige karakteristika i betragtning.

\section{Note}

1. Vi har undersøgt disse forskelle i 17 kvalitative interviews med praktiserende fysioterapeuter, og formandens udsagn er repræsentativt for opfattelsen hos alle disse fysioterapeuter.

\section{Litteratur}

Alonso, Pablo \& Gregory B. Lewis (2001). "Public Service Motivation and Job Performance: Evidence from the Federal Sector", American Review of Public Administration, vol. 31, no. 4, pp. 363-380.

Andersen, L.B., L.H. Pedersen \& T. Pallesen (2009). ”Does employment sector matter for professionals' public service motivation?" Paper presented at the 2009 International Public Service Motivation Research Conference in Bloomington, Indiana.

Baron-Cohen, S. (2003). The Essential Difference: The Truth about the Male and Female Brain. New York: Perseus Books Group.

Baron-Cohen, S., R. Knickmeyer \& M.K. Belmonte (2005). "Sex differences in the brain: implications for explaining autism", Science, vol. 310, pp. 819-823. 
Baron-Cohen, S. (2007). "Sex Differences in Mind: Keeping Science Distinct from Social Policy", i S.J. Ceci \& C.L. Williams (red.), Why Aren't More Women in Science? Washington D.C.: American Psychological Association.

Beck Jørgensen, T. \& L.B. Andersen (2010). "Værdier og motivation i den offentlige sektor", Økonomi \& Politik, 83. årg., nr. 1, pp. 34-46.

Bright, Leonard (2005). "Public Employees With High Levels of Public Service Motivation: Who Are They, Where Are They, and What do They Want?", Review of Public Personnel Administration, vol. 25, no. 2, pp. 138-154.

Camilleri, E. (2007). "Antecedents affecting public service motivation", Personnel Review, vol. 26, no. 3, pp. 356-377.

Connellan, J., S. Baron-Cohen, S. Wheelwright, A. Batki \& J. Ahluwalia (2000). "Sex Differences in Human Neonatal Social Perception", Infant Behavior and Development, vol. 23, pp. 113-118.

Coursey, D.H. \& S.K. Pandey (2007). "Public Service Motivation Measurement: Testing an Abridged Version of Perry's Proposed Scale", Administration \& Society, vol. 39, pp. 547-568.

DeHart-Davis, L., J. Marlowe \& S.K. Pandey (2006). "Gender dimensions of public service motivation", Public Administration Review, vol. 66, no. 6, pp. 873-887.

Eisenberg, N., R.A. Fabes, M. Schiller, P. Miller, G. Carlo, R. Poulin, C. Shea \& R. Shell (1991). "Personality and Socialization Correlates of Vicarious Emotional Responding", Journal of Personality and Social Psychology, vol. 61, no. 3, pp. 459-470.

Feingold, A. (1994). "Gender Differences in Personality: A Meta-analysis", Psychological Bulletin, vol. 116, no. 3, pp. 429-456.

Han, S., Y. Fan \& L. Mao (2008). "Gender difference in empathy for pain: an electrophysiological investigation”, Brain Research, vol. 1196, pp. 85-93.

Hondeghem, Annie \& James L. Perry (2009). "EGPA symposium on public service motivation and performance: Introduction", International Review of Administrative Sciences, vol. 75, pp. 5-9.

$\mathrm{KL}$ (2009). Fysioterapeuter bruger handicappede som kastebolde $i$ strid om okonomi. Pressemeddelelse. http://www.kl.dk/Dokumenter/Artikler/JHE/2009/10/Fysioterapeuter-bruger-handicappede-som-kastebolde-i-strid-om-okonomi/ (120310).

Leisink, Peter \& Bram Steijn (2009). "Public service motivation and job performance of public sector employees in the Netherlands", International Review of Administrative Sciences, vol. 75, pp. 35-52.

Lewis, G. \& S. Frank (2002). "Who wants to work for the government?", Public Ad ministration Review, vol. 62, no. 4, pp. 395-404.

Jennings, M. Kent (1977). "Gender Roles and Inequalities in Political Participation: Results from an Eight-Nation Study", The Western Political Quarterly, vol. 36, no. 3, pp. 364-385. 
Nielsen, Vibeke Lehmann \& Heidi Salomonsen (2010). "Mænd og kvinders adfærd i den offentlige sektor", Økonomi \& Politik, 83. årg., nr. 1, pp. 65-79.

Perry, James L. (1996). "Measuring public service motivation: An assessment of construct reliability and validity", Journal of Public Administration Research and Theory, vol. 6, no. 1, pp. 5-24.

Perry, James L. (1997). "Antecedents of Public Service Motivation", Journal of Public Administration Research and Theory, vol. 7, no. 2, pp. 181-197.

Perry, James L. \& Lois R. Wise (1990). "The Motivational Bases of Public Service", Public Administration Review, vol. 50, pp. 367-373.

Perry, James L. \& Annie Hondeghem (2008). "Editors' introduction", pp. 1-14 i J.L. Perry \& A. Hondeghem (red.), Motivation in Public Management. The Call of Public Service. Oxford: Oxford University Press.

Siim,Birte(1999).”Feministiskeperspektiverpådemokratiogmedborgerskab”, pp. 81-110 i Aronsson et al. (red.), Demokrati och Medborgarskap. Demokratiutredningens forskarvolym II http://www.regeringen.se/content/1/c4/12/50/6457dc6a. pdf\#page $=81 .(100310)$.

Steen, Trui (2008). "Not a Government monopoly: The Private, Nonprofit and Voluntary Sectors", pp. 203-223 i James L. Perry \& Annie Hondeghem (red.), Motivation in Public Management. The Call of Public Service. Oxford: Oxford University Press.

Steinhaus, C.S \& J.L. Perry (1996). "Organizational commitment: Does sector matter?”, Public Productivity \& Management Review, vol. 19, no. 3, pp. 278-288.

Stivers, Camilla (2000). Bureau Men, Settlement Women. Lawrence: University Press of Kansas.

Vandenabeele, Wouter (2008). "Government Calling: Public Service Motivation as an Element in Selecting Government as an Employer of Choice", Public Administration, vol. 86, no. 4, pp. 1089-1105.

Vandenabeele, Wouter (2009). "The mediating effect of job satisfaction and organizational commitment on self-reported performance: more robust evidence of the PSM-performance relationship", International Review of Administrative Sciences, vol. 75, pp. 11-34.

Welch, Susan (1977). "Women as Political Animals? A Test of Some Explanations for Male-Female Political Participation Differences", American Journal of Political Science, vol. 21, no. 4, pp. 711-730.

Yang, C.Y., J. Decety, S. Lee, G. Chen \& Y. Cheng (2009). "Gender differences in the Mu rhythm during empathy for pain: An electroencephalographic study", Brain Research, vol. 1251, pp. 176-184. 